\title{
Schools of government: comparative study
}

Pedro Paulo Teófilo Magalhães de Hollanda

Instituto Brasiliense de Direito Público (IDP)

Samantha Albano Amorim Cardoso

Ministério da Mulher, da Família e dos Direitos Humanos (MMFDH)

Ciro Campos Christo Fernandes

Escola Nacional de Administração Pública (Enap)

Cláudia Henriqueta Conde Rosa

Escola Nacional de Administração Pública (Enap)

The schools of government perform a central role to the public service of many countries. Despite being a disseminated and well-established phenomenon, the functions and even the concept of schools of government vary. Aiming to portray the functions and characteristics of schools of government around the world and offer a better understanding of them, this paper presents a comparative study of schools of government located across six continents. Based on purposive sampling, eight schools of government were selected to be part of this in depth study: École Nationale d'Administration, ENA - France; Canada School of Public Service, CSPS - Canada; Instituto Nacional de la Administración Pública, INAP - Argentina; Australia and New Zealand School of Government, ANZSOG - Australia and New Zealand; Civil Service College, CSC - Singapore; National School of Government, NSG - South Africa; Direcção Geral da Qualificação dos Trabalhadores em Funções Públicas, INA - Portugal; and Escuela Superior de Administración Pública, ESAP - Colombia. Data collection procedures included interviews and document analysis. Data were analyzed using content and comparative analysis. This study highlights some important dimensions of schools of government including the position within the government, funding, main activities, organizational structure and personnel. Other similarities (e.g. among members of Commonwealth) and possible common trends and innovation challenges are also discussed. Finally, we discuss the results comparing them to previous studies findings.

Keywords: schools of government; comparative study; state capacity.

[Artigo recebido em 30 de junho de 2016. Aprovado em 4 de novembro de 2019.] 


\section{Escuelas de gobierno: un estudio comparativo}

Con el fin de presentar las funciones y características de escuelas públicas alrededor del mundo y ofrecer una mejor comprensión de estas organizaciones, este trabajo presenta un estudio comparativo de las escuelas públicas ubicadas en cinco continentes. Sobre la base de un muestreo intencional se seleccionaron ocho escuelas de gobierno para participar en este estudio en profundidad: École Nationale d'Administration, ENA - Francia; Canada School of Public Service, CSPS - Canadá; Instituto Nacional de la Administración Pública, INAP - Argentina; Australia and New Zealand School of Government, ANZSOG - Australia y Nueva Zelanda; Civil Service College, CSC - Singapur; National School of Government, NSG - Sudáfrica; Direcção Geral da Qualificação dos Trabalhadores em Funções Públicas, INA - Portugal; y Escuela Superior de Administración Pública, ESAP - Colombia. Los procedimientos de recolección de datos incluyen estudios documentales y entrevistas. En este estudio se exploran algunos aspectos importantes de las escuelas de gobierno como la ubicación dentro del gobierno, las finanzas, las actividades principales, la estructura organizacional y de personal. También se discuten algunas similitudes (por ejemplo, entre miembros de la comunidad) y posibles tendencias y desafíos. Por último, los resultados son comparados con los resultados de investigaciones previas.

Palabras clave: escuelas de gobierno; estudio comparativo; capacidades estatales.

\section{Escolas de governo: um estudo comparativo}

As Escolas de Governo desempenham um papel central no serviço público de muitos países. Apesar de ser um fenômeno disseminado e bem estabelecido, as funções e até o conceito de Escolas de Governo variam. Com o objetivo de retratar as funções e características das Escolas de Governo ao redor do mundo e oferecer uma melhor compreensão sobre elas, este artigo apresenta um estudo comparativo de Escolas de Governo localizadas em cinco continentes. Com base em amostragem intencional, oito escolas do governo foram selecionadas para fazer parte deste estudo aprofundado: École Nationale d'Administration, ENA - França; Canada School of Public Service, CSPS - Canadá; Instituto Nacional de la Administración Pública, INAP - Argentina; Australia and New Zealand School of Government, ANZSOG - Austrália e Nova Zelândia; Civil Service College, CSC - Cingapura; National School of Government, NSG - África do Sul; Direcção Geral da Qualificação dos Trabalhadores em Funções Públicas, INA - Portugal; and Escuela Superior de Administración Pública, ESAP - Colômbia. Os procedimentos de coleta de dados incluíram entrevistas e análise de documentos. Os dados foram analisados por meio de análise de conteúdo e análise comparativa. Este estudo destaca algumas dimensões importantes das Escolas de Governo, incluindo a posição dentro do governo, financiamento, principais atividades, estrutura organizacional e pessoal. Outras semelhanças (e.g. entre membros da Commonwealth) e possíveis tendências e desafios de inovação comuns também são discutidos. Finalmente, os resultados são discutidos comparando-os aos resultados de estudos anteriores.

Palavras-chave: Escolas de Governo; Estudo Comparativo; Capacidades Estatais. 


\section{Introduction}

The concern about state capacity and efficiency is pressing. There is a need to optimize public expenditure in all levels and fields. Workforce size and performance are also key concerns that take part into countries' agendas. These are common descriptors that fit most of the countries nowadays.

State capacity can be analyzed using different approaches, and one of the most studied approaches is the administrative capacity. Administrative capacity is also considered a dimension that constitutes state capacity and consists in the potential for implementation of public policies (CINGOLANI, 2013). A necessary condition for administrative capacity enhancement is the existence of a professional bureaucracy (public servants) provided with necessary resources and tools. Souza (2016) affirms that the quality of bureaucracy and level of professionalization are some of the main predictors of public policy effectiveness. Thus, we can affirm that public servant training is a major factor in achieving a desired level of administrative capacity.

One way to enhance administrative capacity is investing in public civil servant formation. This is based on the idea that the performance on the organization level reflects the performance in lower levels of the organization. Thus, we assume that by enhancing the capacity of individual civil servants, a country would be contributing to overall state capacity enhancement. This is consistent with the idea of using public servant training as a means of increasing efficiency, innovation and their capacity of helping governments to achieve their goals.

Accordingly, McCourt (2013) points out that "There is no doubt that capacity affects performance (...). But we have learned that capacity-building is rarely effective in an organizational vacuum" (p. 4-5). Therefore, in the design of civil servants' learning activities (for example, courses), specific organizational characteristics such as culture, management practices, communication networks and activities (etc.) must be considered. In this context, it is imperative to highlight the central role played by the schools of government. These institutions tend to perform learning activities based on a strongly applied perspective, which conform with the specific context of public service and their institutions as well as their servants' professional experiences.

Schools of government play a central role in the formation of public civil servants. However, there is some controversy among practitioners and researchers about the concept of schools of government. This controversy reaches a point where some research reports chose to omit schools of government definitions and simply point out that they are considered to be "the institutions which participated in the study" (for example, OECD, 2017). To avoid the risk of calling incomparable institutions by 
the same term we chose to define schools of government as government institutions engaged in capacity building, training and development of public servants and agents.

This study aims to present a comparative study between eight schools of government based on a multidimensional framework of analysis. The dimensions explored were: organization of civil service and recruitment policy, institutional location, institutional trajectory, institutional objectives, funding, personnel, organization structure and activities (learning, research, consulting, events, cooperation and networks). In this era of reduced training budgets and a growing call for expenditure efficiency it is especially important to become aware of other experiences which can support future changes in the management of schools of government.

\section{Theoretical framework}

The comparative analysis was based on a framework of aspects which each have a set of questions that guide our search (refer to Table 1). The original framework development is presented elsewhere (FERNANDES, 2017).

\section{Table 1 - Theoretical dimensions and guiding questions}

\begin{tabular}{|c|c|}
\hline Dimensions & Guiding questions \\
\hline $\begin{array}{l}\text { Organization of civil service } \\
\text { and recruitment policy }\end{array}$ & $\begin{array}{l}\text { How is recruitment to the civil service carried out? Does } \\
\text { the School play any role in this process? }\end{array}$ \\
\hline Institutional location & Where is the school located in the public administration? \\
\hline Institutional trajectory & $\begin{array}{l}\text { When and how was the School created? } \\
\text { What are the main milestones in the School's history? }\end{array}$ \\
\hline $\begin{array}{l}\text { Institutional objectives } \\
\text { (mission and vision) }\end{array}$ & $\begin{array}{l}\text { For whom are the School programs oriented? Public } \\
\text { servants in general, specific careers or hierarchical } \\
\text { level, political agents, citizens? }\end{array}$ \\
\hline Funding & $\begin{array}{l}\text { Is the school funding based on general public budget, } \\
\text { own resources or both? }\end{array}$ \\
\hline Personnel & $\begin{array}{l}\text { Does the School have permanent staff? Both } \\
\text { administrative and instructors/teachers? What is the } \\
\text { process of selection and hiring? }\end{array}$ \\
\hline Organization structure & How is the organizational structure organized? \\
\hline $\begin{array}{l}\text { Activities (learning, } \\
\text { research, consulting, } \\
\text { events, cooperation and } \\
\text { networks) }\end{array}$ & $\begin{array}{l}\text { What are the regularly performed activities of the } \\
\text { School? }\end{array}$ \\
\hline e: Author's own table. & \\
\hline
\end{tabular}


In order to confer standardization and mitigate eventual misinterpretations, we present the terminology adopted regarding the learning subdimension, which covers the main (core) activities were undertaken by the selected schools of government. Terminology and definitions can be seen in Box 1.

\section{Box 1 - Note on terminology}

Schools of Government or Schools is the term used to refer to government institutions engaged in capacity building, training and development of public servants and agents.

Mandatory induction courses describe the obligatory courses that take place in the selection process or at the point a new public servant enters the civil service.

Improvement courses are learning activities, which are required for career progression.

Continuous learning is the term used to describe short-term courses to ensure lasting development of competencies and improvement of professional skills throughout careers.

E-learning refers to distance courses, mainly online based.

Source: Author's own table.

\section{Outcomes of previous research}

Previous research with schools of government as unit of analysis adopted different approaches compared to the analysis undertaken in this study. Prescott (2014) and Ferrarezi and Tomacheski (2010) focused on both specific groups and aspects of schools of government. Prescott (2014) investigated the relationship between research and curriculum development in five national schools of government (or similar organizations related to public servant training organizations). The Schools studied were these: the Australia and New Zealand School of Government (ANZSOG); the Civil Service College (Singapore); the National School of Government (United Kingdom); the Nederlandse School voor Openbaar Bestuur (NSOB) (The Netherlands) and the Bureau Algemene Bestuursdients (ABD) (The Netherlands). Ferrarezi and Tomacheski (2010) investigated offers of training and development programs by Brazilian schools of government of the Rede Nacional de Escolas de Governo (National Network of schools of government) - mainly the themes covered by their courses.

A study undertaken by Oliveira and Rubin (2013) addressed the role of schools of government in the evolving scenery of public administration education in Brazil. 
Aires, Salgado, Ayres and Araújo (2014) aimed to trace the panorama of Brazilian schools of government while Jesus and Mourão (2012) conducted research comparing eight schools of government adopting a specific focus on organizational knowledge. It is clear that the majority of studies addressing schools of government adopt a national approach or focus in specific aspects related to schools of government as seen in the previously mentioned studies.

The OECD conducted some researches (e.g. OECD's 2014 Survey of schools of government) that go in a different direction adopting an international and broad approach. This is the approach adopted in this study. The findings of the OECD's studies will be compared to ours in the section 6 .

\section{Method}

The research was undertaken using a qualitative approach. The empirical basis of this paper is a multiple case study consisting of seven cases of national schools of government. We investigated multiple cases to understand the differences and similarities between them. The cases have been chosen to represent a wide range of contexts. The cases were also defined based on the School's national presence (or lack thereof). Based on a geographic criteria aiming to collect data of at least one school per continent the selected schools were:

The selected schools were:

- two European Schools, École Nationale d'Administration (ENA - France) and Direcção Geral da Qualificação dos Trabalhadores em Funções Públicas (INA - Portugal);

- two Schools from South America, Instituto Nacional de la Administración Pública (INAP - Argentina) and the Escuela Superior de Administración Pública (ESAP - Colombia);

- one School from North America, the Canada School of Public Service (CSPS - Canada);

- one School from Africa, the National School of Government (NSG - South Africa);

- one School from Asia, the Civil Service College (CSC - Singapore);

- one School from Oceania, the Australia and New Zealand School of Government (ANZSOG - Australia and New Zealand).

The data were collected using documentary research (notably the investigation of official websites, legal acts, articles and reports) and interviews (conducted by phone and/or by e-mail). Both interviews and documentary research were based on 
a standard set of questions derived from the underlying analytical framework (see Table 1). The data collection was carried out from August 2015 to March 2016. Data were analyzed using content analysis. An extensive research report was published (ROSA \& HOLLANDA, 2017) presenting the data collected and a preliminary analysis.

\section{Results of comparison}

The results will be presented aiming to highlight the differences and similarities between the Schools investigated on each of the dimensions that guided the analysis.

\section{Civil service recruitment policy}

Regarding civil servants recruitment policies, two main categories are highlighted: recruitment by public admission exams (such as in France, Portugal and Colombia) and recruitment by regular (similar to private sector) selection processes (Argentina, South Africa, Singapore, Australia and New Zealand). In Canada, the selection processes can be centralized or decentralized. The centralized selection process usually occurs to the so called transverse positions, present in almost all organizations and whose selection process can be conducted by the Canada Public Service Commission. The decentralized selection process is usually used to select servers to specialized technical posts whose recruitment process is in charge of government ministries or agencies.

In the cases of Australia, New Zealand and Singapore, the processes of recruitment and remuneration keep similarities: following a minimum legislation, they are directly in charge of the institution's main manager, who is responsible, under a management agreement, for the results delivered by him and his team. Based on the individual server productivity, the manager can set pay increases and extra compensation by allocating the received budget.

The case in Singapore is particularly interesting because public service entrance occurs in a similar manner to private sector entrance - they see the private sector as a competitor in the search for top talented workers. In the Singapore recruitment process, vacancies (job opportunities) in the public service are published on a single website and there is flexibility and autonomy to negotiate different salaries for each post. This is an interesting example of how the flexibility in the public sector can be increased and new forms of employment can be used to attract and retain talent.

In order to attract and retain young talent, a similar recruitment approach to that of Singapore has been adopted in Australia and New Zealand and Canada recruitment is more flexible and has similarities to the private sector; contracting 
and promotion arrangements have also been adopted by these three governments. It is worthwhile noting that these similarities, not only in public service recruitment processes, but also in other aspects analyzed, are more marked in former British territories (mostly members of the Commonwealth).

Those initiatives to attract the best workers and aggressively compete with the private sector were a priority to many countries. To fight the lack of interest surrounding public careers, Canada, Netherlands, Portugal and Singapore went to universities campus seeking new talents (PUMA/HRM, 2000; ROBINSON, 2015). Otherwise, United Kingdom, France and Sweden centralized their policies and procedures that define the recruitment process even if it occurs in the local level (SELDEN, 2003). Germany, Denmark and Norway have more decentralized systems (SELDEN, 2003). However, both aim to employ the best workers and reduce their staff turnover. Japan and Switzerland adopted laws and policies that facilitate people transferring between public and private sectors (SELDEN, 2003). Finland, Netherlands, the United Kingdom and New Zealand launched public relations campaigns to attract young residents to be part of the civil service (PUMA/HRM, 2000). Canada made use of a magazine, $A$ day in the life of the public service of Canada, which published motivational stories about public servants (PUMA, 2001).

Competition with the private sector lead to an increase in public servant salaries, however, due to the 2008 global financial crisis, more than 75 percent of OECD countries planned to reduce their workforce (OECD, 2011). Some have already reduced their workforce drastically (OECD, 2010). Due to this lack of economic stability one of the main concerns of governments is how to continue delivering quality public services with a reduced workforce (SELDEN, 2012).

\section{Institutional location}

The legal status of the Schools are very similar - with the exception of ANZSOG, which represents a unique form of collaboration between two governments (Australia and New Zealand) and universities, and INA, which, in addition to teaching, also works in recruitment, selection and mobility of public servants. Similarities of Schools lie in the legal founding acts (usually in the form of laws, proclamations, acts or decrees) and the mandates, which define their extent and scope of work, activities, target audiences and funding models.

The eight surveyed Schools are located at the federal or central level of the government and mainly aim to recruit and develop federal civil servants. Furthermore, the target audience of NSG initiatives also include the civil servers of provinces and municipalities and ESAP initiatives target audience besides including servers at all levels of government, offers courses to private sector workers and 
citizens in general. Regarding this issue, ANZSOG is an atypical case as it is dedicated particularly to the training of executives from both countries (Australia and New Zealand) and coexists, due to target audience segmentation, with the Strategic Centre for Learning and Development in Leadership of Australia and the New Zealand Leadership Development Center.

The position and location of the schools within the government structure has a direct link with their relevance to the public service. ENA trajectory is the most significant example of a School of Government that has remained highly influential over the years. We can affirm that the influential role played by ENA rests in its proximity to the decision center. Many of the France top-tier public managers (including prime ministers and ministers) are ENA alumni.

\section{Funding}

The funding of schools of government is done, in general, through grants or government transfers based on the general budget (indirect funding) and direct funding through the charging of enrollment taxes, selling of products (publications, facilities rental) or learning services (consulting, technical assistance, coaching, mentoring, etc.). It should be noted that there are some peculiarities regarding this issue. In NSG, the funds raised from the sale of products and services are deposited into an account called the Training Trading Account (TTA) and are intended exclusively to design courses, produce instructional materials and hire teachers. ANZSOG is financed by annual transfers from state members (Australian federal government and provinces and New Zealand central government) and contributions from academic chairs in addition to charging registration fees and enrollment taxes. In CSPS, there is an imminent transition from a full recovery costs model, based on the sale of learning products and services, to a model based on the annual budget allocation, as already occurs in the ministerial context.

\section{Personnel}

The seven schools of government studied (with the exception of ESAP, Colombia which has permanent staff in both administrative and teaching areas) have a relatively small permanent staff base and mostly make use of temporary hiring mechanisms for their teaching, research and consultancy fields. A common arrangement that has been adopted, particularly by the Schools of France, Canada and Singapore, is to attract both senior servers and academics to their temporary staff. There are two cases that are worth mentioning: the direct involvement of French leaders in the course syllabus formulation at ENA France and the program "Experts-in-Residence", in implementation by CSPS, Canada, through which the Canadian school will recruit 
experts from the public and private sectors to share knowledge and develop contents and instructional material to the School's programs.

Issues that recurrently arose are the attraction and retention of qualified servers. Schools from Canada and Singapore in particular expressed their concern about creating an attractive and creative environment for new talents and future leaders, which favors staff renewal and development, essential to institutions that deal with knowledge and learning.

As application schools, it is observed, if any, a reduced staff of permanent servers oriented to teaching. As previously mentioned, hiring external teachers for a specified time is the dominant practice. The profile of these teachers varies between academics and practitioners, the latter usually being public (which is most common) and private managers, with notable knowledge and recognized expertise in their fields. In addition to this, is common the hiring of foreign experts to teach courses or some disciplines offered by the school, especially in programs oriented to senior public managers and officials. To enable the promotion of learning activities by the agencies themselves, INAP, Argentina, provides a list of more than two thousand potential teachers (practitioners and academics). Thereby the agencies (ministries, departments, etc) can directly hire teachers and organize learning activities.

\section{Organizational Structure}

Although distributed throughout six continents, the Schools in this study have very similar organizational features. Generally, they have a president or a general manager who is assisted directly by directors whose responsibilities are concentrated in the areas of teaching, research and internal management or administration. In addition to this, all Schools have units dedicated to international relations, and in the case of ENA-France, an unit dedicated to European affairs.

Most of the schools have in its structure some kind of board where the main decisions are made (the name varies, e.g. directive board, administrative board, advisory board, consulting council). These units are usually composed of public managers, academics, invited notables, teachers delegate and students delegate. Their usual functions are to (1) contribute to the definition of guidelines that guide the strategic planning processes of Schools (medium and long-term goals), monitor the fulfillment of the objectives and the results achievement and (3) support the development and updating of the annual training programs and training and research agendas. In addition to promoting the upgrade and adherence of school's portfolios to the needs arising from public policies and programs implementation, the Boards impel, due to the high degree of authority and reputation of its members, the public service improvement and innovation. 


\section{Institutional Objectives}

Regarding the institutional objectives, if we consider together the missions of the surveyed schools and take into consideration the results of the Organization for Economic Co-operation and Development Report on schools of government (OECD, 2017; OECD, 2014a), it is possible to affirm that the schools of government are institutions established to support learning in the public sector. They play this role by directly offering training programs and indirectly by promoting a culture of learning that contributes to efficiency and effectiveness enhancement of the public sector. However, to remain relevant and responsive to the changing needs of governments and civil servants, Schools should adapt their programs to train current and future public servants to properly fulfill their job's demands. It is worth mentioning the peculiarities of ESAP, Colombia, which is both a government school and a university and INA, Portugal, which includes among its activities, besides the training programs, assignments related to recruitment, selection and mobility of public servants.

\section{Learning}

Concerning the learning activities, the schools core business, there are many aspects to analyze. Concerning the mandatory induction courses, just ENA has a long term course, structured in 24 months and as a phase of the civil service admission exam. In the other studied schools they opt to promote shorter courses, usually obligatory, to take a job in the public service. In general, this courses, which can also be named initial courses or familiarization courses, address general topics regarding the functioning of public administration. These courses offer fundamental contents and initial orientations to public servants.

The continuous learning activities usually consists in a varied range of courses and events offered to public servants (individually) and to organizations. Face-to-face, blended and distance learning courses are the modalities most commonly used to promote the permanent formation of servants of all hierarchical levels. Depending on the public segmentation more methodologically sophisticated products can be adopted such as coaching, mentoring and communities of practice.

While in ENA there is a prevalence of induction courses oriented to the intense training of future senior officials, countries like Canada, Singapore, Portugal, Colombia, Australia and New Zealand, promote shorter initial training courses, investing more heavily in training their servers throughout their careers. Despite not having a clearly established link between training and career development in those countries, learning is seen as an essential asset, a requirement for assuming management and direction positions. 
Canada is an emblematic example in this issue. Although managers and directors oriented courses are not, mostly, obligatory, the culture of learning valorization permeates the federal public service and is favored by annual plans of learning elaborated jointly by managers and their subordinates. CSPS is distinguished also due to the coordination of ten communities of learning as a way to stimulate the permanent learning and the exchange of experiences between its alumni. ENA in its turn has a varied portfolio for training of French, European and foreign servers. Although training for careers has worth it national and international recognition, Europeanization is an important phenomenon for the school, which recently self titled as "European School of Governance".

Also regarding the field of continuous education, it is common to all schools the offer of managers development and leadership programs. There is a common sense that the training of managers and leaders is essential to improve public policies management to cope with crisis situations and drive organizational changes.

Another phenomenon observed is the increasing offer of e-learning courses. The offer consists of online courses, with or without tutoring, live broadcasted virtual learning events and audio-learning via computer, tablet or smartphone are some modalities that have been made available to public servers. Besides the cost reduction, the distance learning offer aims to increase the number of trained servers and to promote participants flexibility, accessibility and autonomy.

Canada, France, South Africa, Portugal and Colombia schools have a diversified offer of online products and services. In Singapore and Australia-New Zealand schools there is a different scenario. Both have a clear focus on executive formation/ education. In ANZSOG we have not identified e-learning programs and in Singapore we did, but just a few courses restricted to basic and/or initial issues.

It is worth mentioning that INAP (Argentina) has a virtual campus and national (TeleINAP and Campus 2) and international (Espacio Iberoamericano de Formación) platforms in addition to a collaborative training portal (Capacitar).

Another aspect to be noted in the education dimension refers to an association of schools with universities to offer graduate courses, accredited to the competent institutions of each country, usually the Ministry of Education. The ANZSOG stands out for been associated with 15 Australian universities, while the ENA has partnerships at national and international level (e.g. Germany) to offer graduate courses. In addition to ENA and ANZOG, just ESAP offer postgraduate courses specialization courses and masters.

ESAP is a special case because it is a public entity of academic nature (university), with legal personality, administrative autonomy and independent assets. It has a significant and regular offer of undergraduate, specialization and master courses 
face-to-face and distance, as well as short continuous education programs. Another peculiarity inherent in the "hybrid personality" of ESAP, both university and school of government, relates to its target audience. ESAP offer courses that are open to the enrollment of civil servants from the three branches and levels of government and also to all citizens.

Some distinguished actions developed by Argentina and Canada schools deserve to be highlighted. INAP (Argentina) has an undergraduate scholarship program oriented to civil servants. CSPS (Canada), through the Program "Public Servant-inResidence" encourages the participation of federal executives in research projects and teaching at nearly a hundred Canadian universities. The transfer of the server to the University may extend from six months to two years depending on the project to be developed, which must be approved by the applicant's home public agency.

\section{Research}

There are generally two tendencies in the definition of research agendas of the studied schools. The first is to guide the choice of research topics based on consultations with ministries and key client organizations. The second is to define research topics, due to the need to update the courses syllabus and training and learning events contents. In spite of not being mutually exclusive, the occurrence of the link between research and teaching is most noticeable in the cases of ANZSOG, CSPS and ENA.

\section{Events}

Most schools promote events related to strategic issues of the country political and economic agenda. There are national and international events. The regularity also varies and the focus is mainly on promoting the debate among legislative members, leaders or experts. The most common shapes are major annual events with participation of experts, servers and, in some cases, students and workers of the private sector. Monthly events usually have a reduced scope and involve solely the actors directly involved in the issue.

INA has an interesting initiative called Roadshow of Best Practices. It consists of a cycle of sessions that run through the country in order to deepen and discuss good practices that provoked more interest in an annual conference held by the Institute. The European range of events organized by the ENA (Cafes, Conference and Meetings) on the other hand, reinforce the role of the school in the European political and economic agenda and its intention to become a European governance school, a reference in the training of the continent's leaders. The CEO Forum, 
organized in a partnership between Kennedy School of Government (Harvard University), and the series of events called OECD Dialogues confer on ANZSOG a relevant role in the development of Australia and New Zealand leaders.

Both the ENA as ANZSOG develop annual events oriented to their alumni, as a way to keep active the interest in professional update and qualification and to strengthen the network among them. In its turn, NSG annually hosts a Public Service Instructors Forum, which constitutes an important space for discussing and disseminating innovations in South African human resources legislation and training.

\section{Consulting}

The schools studied perform consulting activities mainly by demand from other government agencies. In addition to responding to requests from other agencies, consulting actions seek to be aligned with government projects. There are also schools, like the INA, Portugal, and CSC, Singapore, which have defined areas of activity. Noteworthy is the case of ENA, which seeks to participate in international, bilateral or multilateral consulting projects.

\section{Cooperation and Networks}

The schools of government studied relate to each other, to institutes of Public Administration, ministries of other countries or international organizations by being part of networks and through cooperation projects. Partnerships have as its object the provision of international training programs, organization and participation in events, discussion and development of joint projects and exchange of experiences. Networks and partnerships occur both nationally and in the regional and international levels.

Noteworthy is the experience of ENA, which operates international cooperation in the field of public administration with more than 120 countries and is associated with the prestigious group of French Grands Écoles (Grand Schools) and to the Pôle Européen d'Administration Publique (European Public Administration Pole). ENA and ANZSOG also maintain an active network with their alumni, through which they publicize their programs and learning events, promote the knowledge and experiences exchange and inspire new learning. ANZSOG Alumni LinkedIn group gives spotlight to the School in a known worldwide online professional network.

Some Schools show a networked action based on some of its particularities. INA, for example, has a strong network that aggregate Portuguese-speaking countries. The same pattern is observed in NSG role in the African Network of Management Development Institutes and in the African Union. INAP and ESAP by their turn, have a strong presence in the Latin American Center for Development Administration 
(CLAD) and a group of joint actions with the Ibero-American School of Administration and Public Policies (EIAPP).

\section{Reflections and conclusions}

The present study and the OECD report (2014a) share the perspective that some aspects such as the institutional form and the insertion of the schools within the government are directly correlated to their influence and relevance to the public service. The OECD survey results shows that the institutional model have a relevant impact on the relationship between the schools and the government as well as on the autonomy of the schools.

In this way, this study identified three models of relationship between Schools and government, being the first two the most common:

- The school is institutionally located within the center of government or very close to it;

- The school is situated within another government department or agency;

- The school is institutionally autonomous, but maintains a formalized relationship with government.

Although not pointing none of these as an ideal model, it is important to consider that the first two types provide an easy access to government priorities, enhancing the possibilities to be responsive to these priorities, while also limit administrative and policy autonomy. On the other hand, the third one gives more autonomy to the schools to develop learning programs, but decrease the access to government priorities and key actors (OECD, 2014a). The present study corroborates this perspective, correlating an influential role played by a school of government and its proximity to government decision centre.

Moreover, many of the respondents claimed to have relationships not only with the government but also with other educational institutions such as national and international universities (OECD, 2014a). This study also shows that the schools of government studied are often part of networks and cooperation projects, allowing them the relationship with other schools, institutes of Public Administration, ministries of other countries and international organizations.

Concerning the constitutional acts, the majority of the schools were established at national government level through a legal instrument, commonly a law or a decree (OECD, 2014a), characteristic also portrayed in the present study. However, a more recent OECD report (2017) reinforces the need to clarify the schools mandates, especially those that were constituted by laws of general application, in order to increase the powers of the schools of government. In addition, both studies present 
that many schools, although established at national level, provides training to the public civil servants of other levels of government and, sometimes, also to nongovernmental stakeholders.

With respect to the organizational structure, OECD (2014a) findings show that the main internal management instance, the one responsible for the management of the School, consists in a head of institution, a board of directors or trustees, a council of members or several bodies jointly. Our findings suggest that the schools usually have a President or General Manager, directly assisted by the Directors of the areas of teaching, research and internal management. It is also common the existence of some kind of board where the main decisions are made.

The OECD study (2014a) points out that traditional classroom training has been the norm considering the teaching methods applied by the schools of government (93\% of the survey respondents). However, it also shows that these institutions are increasingly adopting new approaches, many of them based on the use of information and communication technologies (ICTs). Approximately $50 \%$ of the schools apply other methods like team-based activities and study tours and about $40 \%$ are training public servants by online courses. Additionally, $33 \%$ of the respondent schools are using ICTs to reach a higher number of learners (for example, by mechanisms like webinars and webcasting). This corroborates with our findings about the increasingly use of e-learning mechanisms by schools of government.

Regarding the types of courses offered by these schools, the OECD report (2014b) mentions that about $30 \%$ of the respondents cited the existence of mandatory induction programs of training for new staff, although it was not possible to identify any clear pattern concerning the topics covered by these programs. Other interesting finding is that induction courses tend to be mandatory in countries with career-based civil service. This information confirms our perception that most sampled countries seems to privilege the offering of continuous learning activities rather than initial training courses.

Some schools are also engaged in knowledge development and research activities. According to OECD survey (2014a), 60 percent of the surveyed Schools are engaged in such activities, but only half of these activities consist primarily in applied research.

With regard to the main objective of the research activities, considering the schools of government that have a research program, $89 \%$ indicated the promotion of better public policies, $78 \%$ the deepening of comprehension about the functioning of public service, and $67 \%$ the improvement of public civil service by filling the knowledge gaps (OECD, 2014a). The research areas most mentioned by the respondents were institutional and organizational transformation (46\%) 
and innovation (31\%). In addition, the areas in which the schools offer training courses are mostly a research focus (OECD, 2014a). Finally, the OECD study (2014a) report that the two main inputs considered in the definition of research agenda are assessment of government priorities and discussions with senior public managers. Our findings indicated that the major inputs considered in the definition of research agenda are consultations with ministries and/or key client organizations and the need to update the courses syllabus and training and learning events contents. Both studies noticed opportunities for improving the connection between research, knowledge development and training programs.

The OECD publication (2017), also based on their survey on schools of government, is very useful for practitioners as it presents recommendations on some crucial issues such as how to evaluate the success of schools of government or how to better suit the activities offered with government and learners needs.

There are two limitations in this study that could be addressed in future research. First, the study focused on presenting a broad view of the main aspects of a heterogeneous set of SoG. The large number of investigated aspects, however, prevented the deepening on each aspect. Future studies may deepen in one of the various aspects mentioned in this study. Second, the aim of this study was to better understand the phenomenon, not to identify causal relations. Future studies may investigate the antecedents that explains the variation on each investigated dimension.

Despite the different characteristics and capacity levels of the public organizations covered in this study, it is clear the central role of schools of government is the modernization and innovation of the public sectors of those countries. It also shows the importance of capacity building for the development of a permanent culture of improving public services provided by the state to the citizens.

Investments in training are particularly relevant in times of change and renewal, which are elements inherent in the current system. The focus on the individual, the improvement and product innovation and public services and the intensive use of information and communications technology are challenges faced in the strategic agendas of governments and Schools of Government must be aware, aligned and responsive to these challenges in order to maintain their relevance to public service and society. This comparison between major schools of government of several countries offers a rich framework to correct paths and enhance state capacity. 


\section{References}

Aires, R. F. D. F.; SAlgado, C. C. R.; AYres, K. V.; AraúJo, A. G. D. Schools of government: the Brazilian scenario. Revista de Administração Pública, v. 48, n. 4, p. 1007-1027, 2014.

CINGOLANI, L. The state of State capacity: a review of concepts, evidence and measures. (Working Paper n. 53) Maastricht: UNO-MERIT, 2013.

Fernandes, C. C. C. Análise comparada das escolas de governo na literatura internacional: perfil, tendências e categorizações. Cadernos Enap, v. 43, 2017.

Ferrarezı, E.; TOMACHESKI, J. A. Mapeamento da oferta de capacitação nas escolas de governo no Brasil: gestão da informação para fortalecimento da gestão pública. Revista do Serviço Público, v. 61, n. 3, p. 287-303, 2010.

JesUs, A. M.; MourÃo, L. Organizational knowledge in schools of government: a comparison study. Revista de Administração Pública, v. 46, n. 4, p. 939-968, 2012.

MccouRT, W. Models of public service reform: a problem-solving approach. World Bank Policy Research Working Paper, n. 6428, 2013.

ORGANISATION FOR ECONOMIC CO-OPERATION AND DEVELOPMENT (OECD). Getting it right: restructuring the government workforce. Presentation at the Public Employment and Management Working Party - Annual Meeting, 2010.

. Special feature: public workforce restructuring. In: OECD Government at a Glance 2011. OECD Publishing, 2011.

. National schools of government survey. Paris: OECD Publishing, 2014a. . Skills beyond schools - synthesis report. Paris: OECD Publishing, 2014b.

. National schools of government: building civil service capacity. OECD Public Governance Reviews. OECD Publishing, 2017.

OliveIRA, F. B.; RUBIN, M. M. Public administration education in Brazil: evolution, challenges, and opportunities. Journal of Public Affairs Education, v. 19, n. 4, p. 635-655, 2013.

PRESCOTT, F. Research and curriculum development at national schools of government. Unpublished Masters Dissertation. University of Victoria, Canada, 2014.

PuMA. Country Web Pages. 2001. Retrieved from: <http://www.oecd.org/puma/> Accessed: 05 may. 2016.

PUMA/HRM. Recent developments and future challenges in human resource management in OECD member countries. Background Paper by the Secretariat Paris, 2000. Retrieved from: <http://www.oecd.org/puma/> Accessed: 05 may. 2016.

RoBinson, M. From Old Public Administration to the New Public Service, implications for public sector reform in developing countries. UNDP Global Centre for Public Service Excellence: Singapore, 2015.

RosA, C. C.; HollandA, P. P. T. M. Escolas de governo no cenário internacional: um estudo comparado. Cadernos Enap, v. 43, p. 113-204, 2017.

SELDEN, S. C. Innovations and global trends in human resource management practices. In: Peters, B. G.; PIERRE, J. (Orgs.). Handbook of Public Administration. 
London: Sage, 2003. p. 62-71.

SELDEN, S. C. Global trends in human resource management. In: Peters, B. Guy; PIERRE, Jon. The SAGE Handbook of Public Administration. London: Sage, 2012. p. 87-101.

SouzA, C. Capacidade burocrática no Brasil e na Argentina: quando a política faz a diferença. In: GoMIDE, A. A.; BosCHI, R. R. (Orgs.). Capacidades estatais em países emergentes: o Brasil em perspectiva comparada. Rio de Janeiro: Ipea, v. 1, p. 51103, 2016.

\section{Pedro Paulo Teófilo Magalhães de Hollanda}

Instituto Brasiliense de Direito Público (IDP). Doutor, Mestre e Bacharel em Administração pela Universidade de Brasília Professor do Instituto Brasiliense de Direito Público. Contato: pedro.hollanda@idp.edu.br

\section{Samantha Albano Amorim Cardoso}

Instituição à qual é vinculado: Ministério da Mulher, da Família e dos Direitos Humanos (MMFDH). Mestre em Políticas Públicas e Desenvolvimento pelo Instituto de Pesquisa Econômica Aplicada. Coordenadora-Geral de Conciliação Trabalho-Família e Projeção Econômica do MMFDH. Contato: samantha.cardoso@mdh.gov.br

\section{Ciro Campos Christo Fernandes}

Instituição à qual é vinculado: Escola Nacional de Administração Pública (Enap). Doutor e Mestre em Administração pela Escola Brasileira de Administração Pública e de Empresas da Fundação Getúlio Vargas. Bacharel em Ciências Econômicas pela Universidade Federal de Minas Gerais. Professor do Mestrado em Governança e Desenvolvimento da Enap. Contato: ciro.fernandes@enap.gov.br

\section{Cláudia Henriqueta Conde Rosa}

Instituição à qual é vinculado: Escola Nacional de Administração Pública (Enap). Mestre em Relações Internacionais pela Universidade de Brasília. Bacharel em Relações Internacionais e História pela Universidade de Brasília. Contato: claudia.conde@uol.com.br 